\title{
Application-oriented University Training Model to Explore Journalism--The Jilin Industrial and Commercial College as an Example
}

\author{
Sun Yan \\ Jilin Business and Technology College, Department of Media and Art, 130062 \\ E-mail:619784966@qq.com
}

\begin{abstract}
Through the exploration of the application-oriented university journalism training model, we have established a journalism major application-oriented teaching mode with professional work as the basis, cultivation of the "service capabilities" as the core, practical training as the key to teach reform for the way.
\end{abstract}

Keywords: service capabilities; applied undergraduate; training mode

1. application-oriented university journalism talents training mode

1.1. The training mode of international applied undergraduate education talents

Internationally, there are colleges and universities in the United States-based "application-oriented" training mode. For example, University of Cincinnati "Alternation" mode, Massachusetts Institute of Technology" Undergraduate Research Opportunities Program" mode, Babson college "Entrepreneurship Practice" mode, California University " Personal Professional" mode, Harvard University "School Enterprise Cooperation" mode, Stanford University "Research and Training" mode .The personnel training mode of higher education in the United States gives priority to with production, university-enterprise cooperation, and pays more attention to the cultivation of practice ability.

\subsection{The training mode of domestic applied undergraduate education talents}

Research data on the training mode of domestic applied undergraduate education talents is rich, representative views are as follows: Academician Zhu Gaofeng put forward: Applied education should be centered on ability training, combine theory with practice, greatly strengthen the practical training, combine the production with study road, and education must combine with society. Department of higher education institute director Wu Aihua put forward: To explore the application of talents cultivation of effective way in the direction of reform is production and study cooperation, internationalization, 'learning by doing'". In the thought of the reform is "'Broadcom' and 'professional'". Beijing Union University uses the knowledge, ability and quality structure which built by students and implement of the structure to reflect higher education thoughts. Reform of Beijing Jiaotong University based on CDIO mode on the lecture teaching model.

\section{2. the plight of applied undergraduate journalism talents cultivation in our country}

Journalism and communication professional has become one of the most popular professional colleges and universities in recent ten years. At present, the number of colleges and universities set up professional journalism and communication and the scale of students 
recruitment is ten times more than ten years ago. It is a strongly practical and applied subject so that students must have the basic professional knowledge and strong ability of practical operation. However, on the current situation of the news education, there are the following problems.

\subsection{Lack of a solid professional and curriculum construction}

Professional construction and courses construction is the core content of self construction in higher vocational colleges, which is also the most difficult part. As it became a "popular professional" at the beginning of the professional construction, which led to convergence, teachers, hardware facilities construction shortage, the up-front investment insufficient, the follow-up investment less, professional connotation construction sufficient.

\subsection{Outstanding talent scarcity}

First of all, from the overall structure of teachers, there is a good leader and the outstanding teachers of " Double Scarce" phenomenon, "Double Teachers Type" teachers lack, professional mismatch, the proportion of enterprise part-time teachers too small ; Secondly, from the professional quality of teachers, teachers' knowledge is old and tired, the ability to operate the new machine is poor, less chances to training and professional development is" attaches great importance to the qualification to belittle skill ". The talents who are good at photographing, video-taping, post-production, new media technology and other aspects of course are extreme lack. Thirdly, from the spirit of literacy, teachers are lack of market awareness and service spirit who have narrow field of vision, backward ideas, and conformism. Finally, from the perspective of ability, teachers are lack of scientific research ability, teaching ability and scientific research transformation ability, marketing ability, innovation ability, (for all sectors of society) negotiation skills, etc.

\subsection{The practice teaching can not get effective support}

Journalism and communication industry has increasingly become a "high input, high output" industry. The journalism education has gradually entered the field of education high input. Equipment and consumables required for photography, camera, advertising design course teaching requires a large amount of funding support, so it can not complete the teaching task if lack of the related test equipment. In addition, reform of experimental field and management of experimental training, software and hardware equipment update all are in need of funds to continue to invest, these factors will inevitably result in the teaching of journalism and communication cost rising. In fact, the school provides the number and quality of practice opportunities for students, which directly affects the quality of students, while lacking of funding has become a constraining bottleneck for journalism and communication professional to strengthen practice and improve students' practical ability.

\subsection{There is no mature teaching mode}

Represented by our college set up some new journalism, and the teaching plan and teaching methods mostly follow the original professional model. Such practice in the start-up period has its rationality, it not only helps to reduce the cost of teaching, also can better ensure the quality of teaching, buffer the transformation of teachers, Ensure the scale and quality of enrollment. But with the deepening of the process of running school, the continuous expansion of the scale, the "use doctrine" malpractice also gradually 
revealed.

Based on this, we put forward a training mode which "service capabilities" as the training objective. To broaden the students' practice field, guarantee the quality of applied talents training.

3. construct the application-oriented university journalism professional talents training mode

\subsection{The "service capabilities" training as a discipline construction goals}

The so-called "service capabilities" that is the ability of applied undergraduate colleges economic and social services. Its meaning can be divided into "indirect" service capabilities and "direct" service capabilities. The former refers applied undergraduate colleges indirectly through training the student to serve the society; latter refers to applied undergraduate colleges will undertake social welfare obligations, directly involved in the production and business activities to serve the society. The two kinds of ability promote each other: teaching activities appropriate integrated economic construction activities will enhance the teaching efficiency, improve the quality of talent training. The establishment of "service capabilities" as the construction goal requires schools according to their own actual situation in the current to focus on personnel training, or focus on the science and technology service, but it will take the "full service", "walking on two legs" as the ultimate goal of the development in the end. By contrast, they will find there are a lot of problems to be improved in their own schools, which will influence behavior and reform direction. Thus, the effectiveness of speaking, "service capabilities" can play goal of the school development, can become the sharp ideological weapon of their master.

\section{2. "Service capabilities" training as the core of teaching mode}

\subsubsection{Change the teaching concept and change} the state of students' passive learning state

Teach a man how to fish rather than give him a fish. Teachers must change the traditional teaching mode and give priority to with the students' autonomous learning. Teachers should become the counselor of student learning, director and supervisor and make the classroom teaching turn into an interaction, mutual teaching, mutual learning process of common development between teachers and students. Curriculum is designed to speak less and do more, then join the teaching content in the process of doing.

\subsubsection{Teaching Reform}

Refer to the "project teaching" approach to improve students "understanding of knowledge and use of knowledge "capability. The main feature of the project is based on teaching practice-oriented, teacher-led, student-centered, which allows students under the guidance of teachers through the completion of a complete project to learn. It is a teaching activity which needs teachers and students work together through the implementation of a complete project.

\subsubsection{Put "service capabilities" training into practice and training}

Combined with the "service" concept, the students understand practice, professional practice to further broaden the channels in the transverse and longitudinal deepen the depth of the internship practice of the principle to develop new suitable for applied journalism practice content.

Cognition practice makes the transition from a single study Tours to participate in the activity to 
improve skills. Early cognition practice is more emphasis on existing resources and professional-related places to visit, such as museums, newspaper, television, radio, etc During the project research, project team according to the characteristics of students through assisting large activities held by some media outlets to widen the channel of the internship practice and raise the awareness of students in this professional internship.

Professional practice into daily life.In line with the concept of "news comes from life", from improving "service capabilities" perspective arrange community internships. Try to arrange the students to $\mathrm{Pu}$ Yang community, the green garden district, Lin Yuan district offices and other community internships in Changchun to practice, and it can inject vitality for news writing.

The university-enterprise cooperation provides journalism practice base. The new Noda Media Co. Ltd. and Shang layer media advertising company as training bases, established practice and services combined, so that students can learn to give back to society from the participation. Make the Jilin Education Television "Black and White Observation Room" column as a platform to show journalism practical ability.

Increased the recessive internship time. Increased internship preparation and summary stage, the preparation phase contains questionnaire design, finding information, understanding the work of other internships. When the students entered the internship, they can work effectively. After the internship, internship students summarize exchange experiences to prepare for the future into the society.

Since 2009, through our continuous exploration, students practice performance has achieved better effect, and the assessment of students' practical achievements is more diverse, such as a contest grades, The internship into teaching process will further broaden the practice field and also make a better combination of theory and practice, which is to be our research content.

\section{References:}

[1] Yang Chunchun, Liu Junping. The Chinese and Foreign Comparatively Study on Application-oriented Training Model [J]. Nanjing Institute of Technology (Social Sciences Edition), 2007 (03)

[2] Sun Yan, Wu Hua. "Service Capabilities" and Guide for the Self-construction-oriented of Higher Vocational Education - in Anhui Province [J].Modern University Education. 2007 (04). 